\title{
Re-assessing the 'weight' of translations within the context of translated soap operas
}

\author{
Şirin Okyayuz \\ Bilkent University
}

In translation studies, investigating translations beyond the implications, realities and difficulties of single texts and single language combinations, viewing the larger picture surrounding translations and following the translations through to the impacts they produce wherever they are received, is an integral part of the discipline. The study discussed in this article is an effort to present food for thought for audiovisual translators of soap operas. Turkish soap operas have been aired in 90 countries around the world, reaching over 400 million viewers, according to 2014 statistics from the sector. The aim of the study is to indicate the type of translated soap operas preferred in different regions of the world; to explain, on the basis of feedback from experts, the public and local and international media, why these are watched; and to investigate the translation modes and strategies used to market the translations successfully in the receiver markets.

Keywords: audiovisual translation, Turkish soap operas, impact of translation, subtitling, doublage, remakes, censorship

\section{Introduction}

Translators, generally, 'work on a thin red line' between the actors who decide what is to be translated (i.e., publishing houses, governments deciding public policy, the media) and those who actually sell/use the translated product (i.e., distribution companies, TV channels, readers, viewers). From this perspective, translation becomes the act of producing something in line with the desires of the patrons and in view of the preferences, attributes and realities of the receivers. In marketing terms, the translator reproduces a 'product' which in turn is consumed, and if it is well liked there will be further work for the translator and the intermediary putting the product out on the market. Even though in translation studies terms what is referred to herein as a translation product is essentially a translated text (oral or written), or a translation, the continued stress in using translation product is intentional within the context of this study. 
Thus, studies investigating translated products beyond the implications, realities and difficulties of single texts and single language combinations, viewing the larger picture and realities surrounding translations, translated products and following the impacts of the translation wherever they were received, are also an integral part of the job and in academic terms the discipline. In this vein, sociological approaches to translation studies have gained increasing visibility in recent years. According to Chesterman (2007: 173-174) such sociological approaches to translation may include subjects like the translation market, the role played by the publishing industry and other patrons or agent and translating as a social practice.

The following study is an effort to present food for thought for audiovisual translators of soap operas, in parts of the world where Turkish soap operas have been translated. According to the President of the Professional Union of Broadcasting Organizations, Dursun Güleryüz, Turkish soap operas have been aired in ninety countries in the world reaching over four hundered million viewers (Akyol 2014), making this a lucrative area of work for translators with Turkish in their language combination. Thus, it becomes important to outline what type of translated products are preferred in the different regions of the world; explain, in view of feedback from the experts, the public and local media why these products are being watched; and discuss what translation modes and which translation strategies were used to market the products successfully in the receiver markets.

Turkish soap operas have met with success in Latin America, Africa, the Arab countries, the Middle East, Asia, the Balkans and in some parts of Europe. According to figures obtained from Global Agency, one of the major distribution companies that markets Turkish soaps since 2006, as of the end of 2014 the revenue from Turkish soap operas was 180 million dollars a year, with the target being set at 220-250 million for 2015 (Gök 2015). As can be deduced from the figures, Turkish soap operas have been deemed a success and studies are conducted in the fields of politics, diplomacy, economics, sociology, anthropology and others on the cultural, religious, social, economic and other impacts of these translated products.

There are multiple impacts and implications of these translated products for Turkey and the viewer countries. To cite a few examples:

a. Studies conducted in Turkey by officials state that, politically and diplomatically, Turkish soaps have a very positive impact on the image of Turkey (Akgün 2013; Salem 2011), and may be considered a major tool for Turkey's soft power in the world (Çevik 2014);

b. Studies in the increase in incoming tourism to Turkey attribute the rise to the influence of Turkish soaps (Kimmelman 2010; Zayed 2013; Almutawa 2014), 
and studies have confirmed that the success of Turkish soap operas and the following rise in tourism have changed visa policies in the instigation of visafree entry on inbound tourism in Turkey (Ball 2013);

c. The media in the Balkans, the Middle East and in Japan are producing documentaries on the economic and social effects of the Turkish soaps (Yasser 2015; Moore 2013; Haber Türk 2011);

d. Economic reports in Turkey state that the contribution of these translated products to the national revenue is large (Salem 2011);

e. Sociologists, especially in the Middle East and Africa, are talking about social changes and women's liberation issues (Özyurt 2014; Zayed 2013) higher divorce rates (Ekopolitika 2015) the questioning of roles in male-female relationships (Gubash 2008; Williams 2013), which they believe have gained impetus due to the influence of Turkish soaps;

f. Experts from the Balkans are talking about the rise of feelings of nostalgia and fraternity or rather the rediscovery of countries with cultural, linguistic and social similarities (Moore 2013; Mendillioğlu 2014), there are even instances such as the naming of newborns after soap opera characters in the Balkans and Middle East, and other nations, for example in Latin America, are discovering the universals they share with the Turks (Abramovich 2014);

g. There are reports of negative reactions from local TV markets which feel the omnipresence of Turkish soaps to the detriment of local productions (Jawad 2013; Yusuf 2013; Altamimi 2012);

h. There are religious and social controversies, especially in the more conservative regions of the Middle East (Zayed 2013; Williams 2013) and Central Asian states (Tursunbaeva 2014), with certain groups petitioning for the ban of Turkish soaps in their countries (RFE/RL 2015; Altayl 2013), religious leaders issuing fatwas about Turkish soaps (Buccianti 2010), production companies (Erdbrink 2013) and viewers (Aljazeera 2008);

i. There are adverse reactions from local politicians and national fronts (Makris 2012), especially in countries in the Balkans (Zalewski 2013) and Central Asian countries (Tursunbaeva 2014), as regards this large presence of Turkey in their local media, urging the public to remember grievances of old with Turkey and the threat of allowing the Turkish culture to infiltrate the local culture (Hürriyet 2012; Aljazeera 2014);

j. Reports on Turkey's and Turkish cultures' rising influence in certain regions (Kaya 2014; Matthews 2011) are accompanied by conspiracy theories regarding the powers behind the soaps ranging from these soaps being a political tool of the USA, to Turkey's efforts to idealize its image in an unrealistic fashion (Sinanidis 2015) to the use of such soaps to realize Pan-Turkic or neoOttoman aspirations. 
These studies, ideas and reflections provide an understanding of the importance of the translated products in question. There are multiple production and marketing companies handling the sales and promotion of different Turkish soap operas, making it extremely difficult to provide a comprehensive and exhaustive list of which Turkish soap opera was aired where. According to information from a compilation of resources a non-exhaustive list of some of countries airing Turkish soap operas are: Austria, Afghanistan, Albania, Argentina, Azerbaijan, Bahrain, Bosnia Herzegovina, Brazil, Brunei, Bulgaria, Czech Republic, Chile, China, Croatia, Ecuador, Egypt, Indonesia, Estonia, Georgia, Germany, Greece, Holland, Hungary, India, Iran, Iraq, Japan, Jordan, Kazakhstan, Kuwait, Lebanon, Latonia, Libya, Lithuania, Macedonia, Malaysia, Mauritania, Mexico, Morocco, Nagorno Karabag, North Africa, Amman, Pakistan, Palestine, Peru, Qatar, Republic of Dominic, Romania, Russia, Serbia, Slovakia, Slovenia, South Korea, Saudi Arabia, Somalia, Sweden, Switzerland, Syria, Thailand, Taiwan, Tunisia, Ukraine, United Arab Emirates, Uruguay, USA, Uzbekistan, Vietnam, Yemen.

\section{Reasons behind the success of Turkish soap operas}

The reasons behind the success of any translated product cannot generally be written off as 'the original was very good' or 'it was translated well', there are usually other factors at play especially in the genre of translated audiovisual works. These reasons are worth researching from the translators' perspectives as such data provide, among other things, insight into what audiences like, what sells and what leads to the internalization of the translated product by the receivers.

According to numerous research, academic studies and public surveys there is no single reason why Turkish soaps are popular all over the world, rather there is a plethora of reasons, many of them specific to the region or country.

From a translators' perspective, the success of Turkish soaps around the world can be grouped under four major headings: (a) the product and the producer country, (b) the content and the manipulation of the content, (c) similarities between peoples and creation of empathy and (d) economic and political factors. Of these, the last three are of interest to the translator.

\subsection{Content and the manipulation of the content}

Since translators are major actors in the transfer of content, knowledge pertaining to what sells in their country and what is not well received allows them to formulate their translation strategies and approaches to the material to be translated. One of the reasons cited for the success of the Turkish soaps is the universality 
of the plots. Most of the Turkish soap operas are about classical themes like love, family, suffering and success. Though the translator cannot change themes or plot, a professional translator will be able to adjust the discourse of the translation according to other features of the content such as those given below.

\subsubsection{Portrayal of issues which are taboo in the viewer country}

Media experts, like Professor Aslı Tunç, state that Turkish soap operas are popular in the Middle East because these soaps deal with issues such as gender equality, treason and love affairs, illegitimate children that the Arab television is afraid of dealing with (Williams 2013). The love scenes and the discourse which is tame by the standards of Western audiences but a novelty for Arab countries is also cited as one of the reasons for the popularity of Turkish soap operas with Arab audiences (Williams 2013). An international correspondent in the region states that, Turkish soaps, by virtue of being produced in Turkey, seem to slip by the Middle East and Asian censors, giving the example of Pakistan where soaps like Aşk-ı Memnu (Forbidden Love) and in the Arab countries where Gümüş (Noor in Arabic) are not banned because they are Turkish productions (Vivarelli 2013). It may be concluded that the idea of watching Muslim men and women with the same values and cultural background, but raising taboo subjects and challenging values, the Turkish series may be seen as challenging the system from within, but they are not viewed as threats.

\subsubsection{Focus on family and values}

According to Frederick af Malmborg, managing director of a global distributor of soaps, one of the appeals of the Turkish soaps is that, they take family stories seriously, whereas as, for example, family shows from the USA are usually comedies (Zalewski 2013). An example given for this is, Serbian audiences watch the series because they have the chance to remember old traditional values which are lost in the fast track of ever evolving Serbian daily life such as family ties, and in the case of Greek audiences Turkish soap operas allow the public to remember values such as the importance of family and respect for the elderly (Mendillioğlu 2014).

\subsubsection{Creation of strong women characters}

Experts argue that in the regions where Turkish soap operas are hits, women tend to watch soap operas, thus the women oriented themes of Turkish soaps make them appealing. Studies indicate that women in the Balkans and the Middle East can identify with the desires of the women in the Turkish soaps and women of the regions like seeing women who are strong enough to stand up for themselves (Zalewski 2013). In Latin America, media experts attribute the success of Turkish soaps to the fact that they are melodramas which appeal to 
female audiences (Günerhan 2014). Some of the success of the Turkish soaps such as Kismet (Dudaktan Kalbe in Turkish) have been attributed to the portrayal of liberalized females, which is a novelty in terms of the stereotypical role of traditional females that the Arab audience is familiar with (Athens Owl 2014). Greek filmmaker Paschalidou (2014) states that the Turkish soaps provide an alternative vision of the world across the region from the East to the West, women are treated with respect and love, and there is romance that seems so unreal in their situation. She also adds that the characters and discourse in these types of soaps make women feel they are not alone and thus they decide to break their silence or even take their lives in their own hands. According to sociologist Prof. Aydin Uğur, the balance of liberalization of females in Turkish soaps is just right, in that women are modern but not degenerate (Rohde 2012). According to researchers on Arab media and society, "so great is the effect of this that Turkish soap operas representation of emancipated women on the screen has turned into a battlefield, celebrated by audiences and condemned by religious and political conservative leaders," (Buccianti 2010).

\subsubsection{TV policies in Turkey and censorship making originals acceptable for conser- vative audiences}

RTÜK is the Turkish Radio Television Supreme Council which approves all content of television programs and tends to employ conservative policies. Various media also state that, the viewers in the Middle East and Balkans prefer family dramas which have been shaped according to RTÜK norms in Turkey, since families in certain regions of the world traditionally watch TV together especially in the evenings. Turkish soap opera distributors also allow foreign buyers to censor the soap operas in accordance with more conservative norms, allowing for the cutting out of scenes that foreign audiences or family audiences may find too explicit (Zaman 2014).

\subsection{Similarities and creating empathy}

In order for a translated product to be liked in the country in which it is received, it is important that the translator draw upon certain strategies and approaches that localize the audiovisual products, allow the audience to form empathies and affiliations with the product. The translators may either be hindered or helped by the visual part of the original, but the text is their playing field, if they know what audiences will find familiar and endearing and what will create empathy versus what will not. This is a case in point for studying audience desires for the translation of $\mathrm{AV}$ products, which would allow translators to formulate the translation in ways that would stress similarities causing internalization and empathy. 


\subsubsection{Cultural/linguistic similarities}

Sociologists from Serbia, Kosovo, Albania and Bosnia (Mendillioğlu 2014), executives from TV channels in Bulgaria (Anatolia News Agency 2013), state that local audiences watch the series due to the cultural and linguistic similarities they are able to identify, as cultural references in the shows show similarity to their cultures' social norms and values. Family relationships, lifestyles, character names are easily identifiable for the viewers in those countries (Hamzic 2013). Arab societies on the other hand like the similar portrayal of fidelity, the role of the mother in the family life and collective family life portrayed in the series (Özyurt 2014). According to journalists, the Greeks view the Turkish soap operas as their own, as the attitudes, relations and lifestyles in the Turkish soap operas are the same and most importantly there are fragments of shared, undubbed vocabulary (Moore 2013). In reference to this, Central Asian audiences state that they share the Turkish culture and thus Turkish soaps are popular in these countries (Tursunbaeva 2014).

\subsubsection{Religious/social similarities}

The newspaper Frankfurter Allgemeine Sonntagszeitung cited that one of the reasons for the popularity of Turkish soaps in the Middle East was that there were similarities in the religious practices and social norms of the countries in question (Ekopolitka 2015). In the Arab world viewers of Turkish soaps see the more familiar mosques and hear the use of phrases such as inşallah (if god is willing) which they are more familiar with and thus drawn to. The stress in Turkish soaps is not on Islam or Muslims, but there is a religious similarity which is portrayed through the religious culture of the Turks in the soaps (Haberport 2015).

\subsubsection{Shared history and commonalities}

Anthropologist Penelope Papailias argues that, "the Turkish soap opera phenomenon in Greece shows a fragile cultural engagement between Turkey and Greece and a recognition of their fraternal similarities alongside their deep historical grievances," (Moore 2013). Egypt, having close ties in history to the Ottoman Empire (Yasser 2015), in the case of Pakistan the country's long standing historical ties and exceptional brotherly relations with Turkey is said to have played a role in the popularity of Turkish soaps in these countries (Khawaja 2013).

\subsection{Economic and political factors}

Economic factors surrounding the translation market are far out of the scope of most translators, but the translators have the chance to work around discourses and play up or play down, which ever may be the case, the dialogue to align it with 
the political norms of the receiver country. Thus, the translator also has the chance to highlight issues relating to the aspirations and political desires of the public in the translation. Information concerning the economic and political realities, controversies surrounding translated products allows the translator to rebalance translation strategies and approaches in accordance with what is to be done or is desired to be accomplished with the translated product.

\subsubsection{Portrayal of a synthesis of the West and the East}

There are those who argue that Turkish shows have become popular in the Middle East also due to "the portrayal of Turkey's idealized self-image as a nation balancing its religious identity with Western behavior like drinking wine and kissing," (Krajeski 2012). According to Sibel Akın, who wrote a master thesis on the social and cultural effects of Turkish soap operas, "Arab women are able to see an image of the world they envision for their children where the values of the East dominate but the lifestyle of the West is embraced." This, she states, is one of the reasons why Arab women who are searching for a way for empowerment for women in the region find this synthesis and balance fascinating (Özyurt 2014). Some experts dub the appeal of Turkish soap operas as "the triumph of Western values by proxy," meaning simply that the Muslim context remains the crucial bridge (Kimmelman 2010).

\subsubsection{Social and political changes and aspirations in the viewer country}

Turkish soaps also address serious social issues such as the lives of political prisoners, the decline of rural life, the role of women, raising awareness among the public about such social issues (Krajeski 2012), and thus fuelling aspirations and political change in the region. Sociologist Hülya Uğur Tanriöver states that in Muslim dominated societies people are breaking out of their shells and looking for political, social and cultural models that are close but at the same time different from their own; she further states that the people of Arab world thus already liked the kinds of stories and life styles in the Turkish TV series and that is why they have accepted them (Zayed 2013).

The aspirations of the viewers in different countries may be to create a bond or a rapprochement. For example, according to political scientist Adrian Staudacher, the relationship between Turks and Greeks is still mediated by old stereotypes and self-other categories, but those stereotypes and categories "have changed their significance within the new trans-Aegean discourse" and Turkish soaps have had an impact on this (Moore 2013).

Last but not least, the success of the Turkish soap operas is attributed to the translation modes and strategies used in various countries for a diverse set of reasons. 


\section{Translations of Turkish soap operas}

A large amount of information is available about translated Turkish soap operas, but very little information is provided about the quality of translation or the translation mode.

Some Turkish distribution companies which have grasped the importance of translations in the success of the Turkish soaps abroad state that they fashion and prepare the dialogue lists, musical effects and dubbing texts individually for each country, thus ensuring that the high quality of the production is maintained (Haberport 2015), whether the soaps are to be dubbed or subtitled.

Feral (2011: 392) states that research has shown that the practices, dubbing and subtitling, differ on numerous levels: technical, financial, socio-cultural and political. Flynn (2014) also states that there are different reasons for which subtitling or dubbing would be preferred, and the decision is usually economically, politically or culturally motivated. For example, in the case of Arabic speaking countries, audiovisual translation is catering to a region of three hundred million Arabic speakers and according to contemporary surveys ninety seven million are illiterate, thus for example rendering subtitling a not so preferred strategy if one is to reach large audiences (Gamal 2014).

According to De Marco (2012: 66) the preference to use one method over the other is a "key to understanding how a country perceives itself in relation to others, how it views the importance of its own culture and language." The following sections deal with the translation modes of Turkish soap operas, and where information is available to the use of different translation strategies embraced.

\subsection{Translations of the names of Turkish soap operas}

Domestication strategies are used in the translation of the names of Turkish soap operas predominantly in a wide geography where Turkish soaps are translated. One prevalent strategy in the translations of the names of the soap operas seem to be to simplify these for foreign audiences. For example, Fatmagül'ün Suçu Ne? (What is Fatmagül's Fault?) was simply translated as Fatma or Fatima (Yasser 2015). The name exists in the Muslim cultures and the Turkish version of the name is a longer version of Fatma or Fatima adding on Gül meaning rose in Turkish.

In some instances the names of the series were adapted to attract audiences, the Bulgarian channel Nova Televizia Aires Dudaktan Kalbe (literally From the Lips to the Heart) as Melody of the Heart (Anatolia News Agency 2009). The title of the historical drama Muhteşem Yüzyıl (Magnificent Century) was changed to 'The Sultans Harem' in Arab countries and it was changed to 'Suleiman: El Gran Sultan' 
Suleiman: the Grand Sultan for the MundoFox channel in the USA (Superhaber 2014). The first Turkish soap to be aired on Greek TV, Yabancı Damat (Foreign Groom/Son in Law), a love story between the poor son of a Turkish baklavamaker and the rich daughter of a Greek shipping tycoon, and was aired in Greece under the name The Borders of Love (Rousselin 2013).

It seems to be common practice to shorten or rename the soaps thus better enabling foreign audiences to remember and internalize the names.

\subsection{Dubbed Turkish soap operas}

The choice of the dubbing language in the Middle East and Arab countries allowed broadcasters to reach wider audiences. For example, though other foreign soaps from Latin America have been dubbed in classical Arabic the choice made by distributors MBC to dub Gümüş (Noor) into a conversational dialect of Syrian Arabic which is readily understood by most Middle Eastern viewers was cited as a reason for the resounding success of the series around the region (Oxford Business Group 2015).

Another reason cited for the success of Turkish soaps in the Arab world is the use of Syrian actors such as Maxim Khalil and Laura Abu Asaad, whose voices matched the characters they portrayed and whose voices were familiar to the Arab audiences due to early Arabic dubbing of Spanish telenovelas (Turkish Review 2014).

Previously, foreign soap operas had been dubbed in the Middle East region into classical Arabic, but the choice to dub Turkish soap operas in a Syrian dialect made the audience feel closer. This choice in dubbing was instigated in 2007 with $\mathrm{MBC}$ and the company states that the choice of the Syrian dialect was due to the fact that previously a Syrian drama Bab al Hara had gained popularity. On the other hand TV shows dubbed into classical Arabic, providing a rigid dialogue, clashed with the informality of the shows (Williams 2013). There are others who share the opinion that the allowance the Egyptians showed for dubbing into the Syrian dialect increased the demand for such series and was a major factor behind the success of series such as Gümüş (Noor) and Aşk-ı Memnu (Forbidden Love) (Altamimi 2012).

There are other languages used for dubbing Turkish drama series in the Arab world besides the Syrian dialect, for example the use of the Lebanese dialect (Zayed 2013).

Diaz Cintas (2009: 283) states that dubbing "is more oriented at a target audience and that makes the translator adapt the original text in certain ways as it has to meet the standards existing in the target language and or country." One of the most influential and successful soap operas to be aired in the Arab world was 
Gümüş (Silver) in which the translators chose to change the names of the major characters, the male lead being renamed Muhannad and the female lead Gümüş (Silver) was translated as Noor (light). Turkish actors in dubbed TV shows on Arab screens have become known throughout the Arab world by their translated character names (i.e., Muhannad, Amir, Lamis, Noor), and many viewers do not even know the real Turkish names (Bilbassy-Charters 2010). According to Feral (2011: 392) this was a great example of the freedom that dubbing allows in facilitating "adaptation in order to make the film or television show more accessible to the target audience's culture."

Sweden also chooses to dub Turkish soap operas. A new Turkish TV drama that was picked up by Swedish SVT TV channel is Son (The End). A global distributor of soaps argues that, these Turkish soap operas are likely to travel well beyond the Muslim world and audiences in Europe, Asia and Latin America are used to dubbed foreign series. Thus, if the receiving country is going to be dubbing series, he argues, the clever choice would be to take something from Turkey which is really good, instead of something that is mediocre from Los Angeles (Zalewski 2013).

Chile is also one of the countries that opts for dubbing Turkish soap operas. Dubbed in Spanish by Chilean actors, Binbir Gece (1001 Nights), has achieved an audience share not seen in years in the South American country and thus reversing the fortune of the TV channel airing the show (Abramovich 2014). Since Turkish is not a widely spoken language in Latin America it is interesting to note that the translated version of the Turkish soap Binbir Gece (1001 Nights), which by the way is not the first of the Turkish series dubbed into Spanish in Chile (previous ones are Aşk-ı Memnu (Forbidden Love), Fatmagül'ün Suçu Ne? (What is Fatmagül's Fault), was 'a collective effort'. A Turkish reporter visiting Chile states that upon asking if there were Spanish translators with a good enough command of Turkish to prepare the dubbing texts for the Turkish series she learnt that almost every Turk in Santiago contributed in one way or another to the translation process. The Turkish ambassador to Santiago, Gökçen Kaya, was reported as saying everyone from the secretaries working at the Turkish Embassy to Turkish kebab restaurant owners who had settled in Santiago were asked to edit the translated texts. Part of the success of the dubbing it attributed to the use of Chilean actors who were experienced and had enticing voices (Günerhan 2014).

Another Turkish soap opera that was dubbed in Spanish is Muhteşem Yüzyll (Magnificent Century) aired by the MundoFox channel in the USA (Williams 2013).

Pakistan also dubs Turkish soap operas and the dubbing language is Urdu. The Turkish soap Aşk-ı Memnu (Forbidden Love) was translated as Ishq-e-Mamnoon, an easy translation due to the similarity of the two languages, and Gümüş (silver) 
was translated as Noor (light) (Yusuf 2013). The UAE based channel Urdu1 became available in Pakistan in June 2012 by broadcasting two foreign dramas, one of which was Turkish and much of the success of the series is attributed to the successful dubbing in Urdu (Khawaja 2013).

On the other hand, in another region of the world, there are reports of controversies surrounding the dubbed Turkish series in Iran. In Iran the dubbed Turkish TV series Lale Devri (The Tulip Age) was taken off the air suddenly when one of Iran's most popular satellite channels GEM TV operating from Dubai, United Arab Emirates and broadcasting illegally into the country was taken offline without explanation. Following this, on Dec 16 2012, the semiofficial Tabnak website reported the arrests in Tehran of several people doing Persian voice-overs for the channels other hit Turkish soap opera Muhteşem Yüzyll (translated as The Sultan's Harem). Furthermore, two weeks after the arrests the actor playing the lead role of Sultan Suleiman suddenly changed from a booming bass to a higher squeaky voice, leading audiences initially to laugh but later to protest (Erdrink 2013).

There has also been a rise of the number of dubbed Turkish shows in the Balkans and especially in Macedonia where the dubbed versions are watched with interest. Viewers comment that dubbed versions are preferred by those who have difficulty following the subtitles, and the Macedonians choice of casting good actors for the voiceovers who are themselves recognizable to the Macedonian public was intelligent. Furthermore, the key demographic, housewives, feel they can multitask, for example knit, while watching these dubbed light soap operas which offer relaxation (Hamzic 2013).

\subsection{Subtitled Turkish soap operas}

According to Diaz Cintas (2009: 49) subtitling, as opposed to dubbing, "is an ancillary element added to the finished product." There are countries in which this is the preferred mode of translation for AV products for a multitude of reasons from economy to language policies and politics. For example, Turkish soap operas are translated with Greek subtitles in Greece and there are those who view this as a controversy given the past political, historical ties between the countries, whereas others view it as a peace making tool (Athens Owl 2014). There are others who believe that the subtitled Turkish soaps are basically a dialogue between two cultures which is conducted not in the halls of government, but in the sitting rooms of regular citizens, which due to the similarities both linguistic and cultural between the two countries allows Greek audiences to experience the fragments of shared undubbed vocabulary, thus breaking down old stereotypical self-other categories in the region (Moore 2013). 
Since subtitling allows the audience the opportunity to hear the original, this mode of translation has its advantages when audiences can pick out linguistically similar words and expressions allowing the audience to feel closer to the AV product. There are also advantages to linguistic similarities between the Balkan languages and Turkish when it comes to subtitling. For example, the historical soap opera Muhteşem Yüzyıl (Magnificent Century) was filmed in Turkey in contemporary Turkish, adding in older Turkish words that would not hinder understanding for the Turkish audience. The same applies of course to the Balkan audiences who are watching the show, the dialogues sound familiar and audiences are able to pick up common words in subtitled versions, creating a sense of cultural proximity (Hamzic 2013).

Interestingly, maybe due to lower costs and high literacy rates which affect the choice of this mode, Russia also prefers to air Turkish soap operas with subtitles (Çevik 2014).

\subsection{Adaptations and remakes of Turkish soap operas and Turkish remakes}

Turkey has also been remaking American soaps the like The O.C, Desperate Housewives among many others and some countries are opting to adapt Turkish soaps. A Miami based distributor of TV shows, states that they have sold over ten Turkish soap operas either adaptation rights or complete productions in five Latin American countries (Abramovich 2014).

Turkish production companies are also selling the Turkish remakes of American soap operas like Umutsuz Ev Kadinları (remake of Desperate Housewives), Kavak Yelleri (remake of Dawsons Creek) to other countries. Foreign buyers of these remakes say that the pacing of the Turkish versions of the American soaps seem to suit the audiences in the region better. In an interview with a chief executive of a marketing company the expert states that the Turkish versions are preferred in certain regions because of viewer habits. Audiences in Turkey and similar regions do not like the tempo in American series because television viewers habits are not similar to those of American or Western European viewers. "Families watch shows, keep an eye on their children, serve brewed tea, answer the phone, put children to sleep, help with the child's homework all during the same time slot." When the tempo of the soaps is slower they can watch and do all these at the same time and they are able to follow the subject. They might miss out on a few scenes, but continue to grasp the story and they can always watch the summarized version at the beginning of the next week's episode (Altaylı 2013).

Another reason cited for the preference of Turkish remakes over American originals is because the Turkish remakes are always filmed with the caution that families will be watching the soaps together. Paying attention to sensitive issues 
and taboos allows Turkish remakes a larger success in countries to the south of Turkey (Altayli 2013).

Latin America is also buying Turkish soaps to adapt into their own cultures. Experts on the Latin American soap opera market state that it is was initially difficult for Turkish soap operas to make an entree into the Latin American market, but the success of the Turkish soaps around the world facilitated this in the end. Due to the fact that Latin American channels could not gauge audience reactions initially to the introduction of Turkish soaps into the local market, they started with baby steps, meaning they chose to buy the scripts, stories, formats of the series and remake these with local actors in the fashion that their audiences were used to. The first of these series was the adaptation of Aşk-ı Memnu (Forbidden Love) which was adapted as Pasion Prohibido, where main male character Behlül was localized as Bruno and main female lead Bihter as Bianca (Superhaber 2014). Turkey is also producing adaptations from books into TV drama and marketing these abroad. An interesting example is the adaptation of the Jane Austen novel Pride and Prejudice into a Turkish soap opera Asi which was translated as Rebellious into Arabic and sold to Middle Eastern countries (Oxford Business Group 2015). Further adaptations from novels include a screen adaptation of a 19th century Ottoman novel about a young woman's search for love, Aşk-ı Memnu (Forbidden Love) which was adapted in the Turkish version as a racy love story (Çevik 2014). Also, there is Bir Istanbul Masalı (A Tale of Istanbul) which is a prolonged adaptation of the American film Sabrina.

\subsection{Censorship}

In reference to domestication strategies as defined in cultural terms:

An audio-visual product has to be different enough to be foreign but similar enough to what viewers are familiar with to retain their attention. In a way the 'other' has to be sufficiently similar to us to be accepted. In this respect the needs and expectations of targeted viewers shape the adaptation of the source text (scenario, script, dialogue list). Thus translation may ultimately be involved in exclusively domesticating programs and films, manipulating them to please dominant expectations and preferences, for the sake of target language fluency or reader friendliness, sometimes going as far as reinforcing language purism, censoring dialogues or changing part of plot to conform to target-culture ideological drives and aesthetic forms. Here the translator's ethical principles are challenged. But then, aren't certain types of screen translation (dubbing, voice-over, remakes) in fact instruments of the protectionist use of culture, violating ethical principles to some extent by erasing traces of the other-including his/her voice or his/her speech.

(Gambier 2003:179)

Turkish soap operas have to pass the censors of RTÜK in Turkey before they are aired on television. RTUK is the Radio and Television Supreme Council of Turkey 
and is quite strict in terms of censorship, not allowing what they would view as unsuitable material to be broadcasted. This censorship actually makes it easier for Turkish soaps to be sold to the Middle East and the Balkans where families view such shows (Zaman 2014).

According to Diaz Cintas (2012: 286) "audiovisual media speaks to a larger, more diverse population than written material and therefore must be ...organized in its tastes and opinions by a visible, and invisible, censorial power."

Though censorship is generally not regarded very positively, it is clear that the degree of censoring employed in the translation of Turkish series has not impaired understanding and has contributed to the success of the series in the Arab countries rendering them compatible with mainstream Arab cultural norms.

In 2008, when Saudi-owned, Arabic language satellite television channel, MBC bought the right to the Turkish soap opera Gümüş (Silver) one of the reasons for the success of the series in the Arab world was simply that with this initial series and with others to follow many of the Turkish soap operas were censored of the raciest scenes (Rohde 2012). In some cases, especially in AVT, this is necessary because as De Marco (2012: 68) states, "AVT is the means through which not only information but also the views, the assumptions and the values of a society are filtered."

Even the earliest example of Turkish soaps on Arab media were censored, for example, several scenes were cut from Gümüs (Noor) in consideration of the idea that they were erotic and thus inappropriate and incompatible with the regions values. Even this did not serve to stop criticism as there was a great upheaval from Muslim clerics in the region (Buccianti 2010).

Some of the scenes in one of the later Turkish TV soaps Aşk-ı Memnu (Forbidden Love) threatened to offend Arabs unless it was heavily edited, or rather censored, which was the case. Sengul Ozerkan, a professor specializing on TV shows and conducting surveys about such issues states that "you have to understand that there are people ... who say that they only learned how to kiss or learned there is kissing involved in lovemaking watching Noor," so one you can understand the impact the show had on audiences and why Aşk-ı Memnu needed to be censored (Kimmelman 2010).

The dynamics of censorship and the dubbing process led to successful mediation of the soaps into the Arab cultural context. For example, there were some scenes depicting sexual intimacy between the leads of Aşk-ı Memnu (Forbidden Love) where scenes in which secretive lovemaking were censored because these may have caused male members of the families watching the soap to turn off the TV, as Arab families have a tendency to watch TV together (Turkish Review 2014).

The Arab viewers sensibilities were also considered in the rendering of the dialogue where some of the references were cut out. Oltra Ripoll (2005: 89) argues 
that, "there are some factors of the translators' environment and the target culture that condition the whole translation process."

A scene linguistically censored for the sake of such sensitivities is as follows: In Aşk ve Ceza (Love and Punishment), the female lead has sex for the first time in her life with a man after she learns of her fiancées betrayal. The male partner asks why she chose to lose her virginity in the original dialogue, whereas the dubbed version states something along the lines of 'you wanted to try something new I get it, by why me?' with no reference to virginity. Other instances of dialogue and image censoring can also be cited, for example from the drama Fatmagülüun Suçu Ne? (What Was Fatmagül's Crime?) which is about the gang rape of a blameless young girl Fatmagül, the rape scene is heavily censored in that, the original shows undressing and the ripping of the dress of the victim and fondling, was edited down to Fatmagül's terrified expression and her screams overpowered by the laughter of her rapists in the translated version. In another scene three of her four rapists get together and they are trying to find a way to save themselves from jail. In the scene the fourth culprit hasn't shown up leading one of the rapists to state that 'the opens his zipper, closes it and then thinks it's all over, he can disappear. The translation into Arabic cut out the reference to the zipper as a crude reference to the rape in view of Arab sensibilities (Turkish Review 2014).

\section{Conclusion}

In conclusion, translated Turkish soap operas which have captivated millions from different parts of the world have been investigated more thoroughly by experts from fields such as economics, politics, the media, foreign relations, and by state officials and organs, anthropologists, sociologists and journalists, than by translators. There are probably multiple reasons for this, i.e., Turkish is not one of the most prominent languages among the language combinations of translators and translation scholars, AVT is still not viewed as the most prestigious platform of research in some parts of the world with literature still holding the top slot in prestige, soap operas are not taken very seriously either, furthermore due to the dual nature of the product (audio and visual) and the fact that translators usually have no influence in the production of the visual the role of the AV translator is seen as even smaller than in the translation of other genres and so much more. But, these widely disseminated products that reach the widest audiences around the world are produced through the choices and abilities of translators too and in many cases, they seem to influence people more than other forms of communication. 
It must also be admitted that research about such AV products is hard because it is very hard to quantify or even verify the actual role of cultural items such as soap operas in influencing societies, diplomacy, culture, politics, religious conservatism and the like. But in this respect experts in the field like Çevik (2014) state that "both high culture and popular culture products are equally soft power resources."

Translators are one of the major actors in the production of these products and these AV products are internalized by the viewers and are affecting changes big and small, as well as drawing many reactions and causing controversies. In a sense, since these AV products become bicultural products in translation, (Scott 2011), what these products meant in their original productions in the home countries is not what they end up meaning as they are translated across cultures and languages.

According to the research from other fields, a Turkish soap opera influences divorce rates in the Middle East, a series about an Ottoman sultans' harem coming at the right time in history and political conjuncture allows people to rediscover commonalities in a region, the drama of a single mother raising a child with leukemia on her own bridges gaps between the Atlantic and Mediterranean, a victim of rape portrayed in a social tragedy allows people around the world to rethink women's issues and the list is long. The examples are numerous, the data is essentially unverifiable (i.e., how can one state exactly what led a person to do something or think something), but the facts are clear, audiovisual translations allow the translator to become a major actor in the front trenches of international communication with the masses.

Some translation scholars like Dick (2012: 9) underline the importance of works in translation studies that underline the role of translations - or translated products in this case- in transmitting cultural ideas across borders and languages.

Thus, it is clear that: "In the current media scenario, there is an on-going transfer of power- from the media owners to the distributors and professionals who manipulate (literally speaking) the multiple codes. Translators are a part of this new group but do not yet realize what this implies or recognize its full effects." (Gambier 2006: 2) And furthermore, "In this changing mediascape, the translators have and will have a major role, if they fully realize their social-cultural function." (Gambier 2006: 7).

Further research into translation of AV products taking into account larger perspectives such as the political, economic, social effects would provide not only food for thought for translation scholars, but would also be extremely beneficial in providing material in the design of university courses to meet market needs and requirements. It would also enable translators to rethink and reassess the importance of the profession on a global perspective and the time for this seems to be ripe. 


\section{References}

Abramovich, Paulina. 2014. “Turkish soaps invade Latin America, land of telenovela”. Business Insider, December 23. http://www.businessinsider.com/afp-turkish-soaps-invade-latinamerica-land-of-telenovela-2014-12\#ixzz3cmDf3irY.

Akgün, Mensur, et al. 2013. TESEV Dış Politika Programı:Ortadoğu'da Türkiye Algısı. Online edition. http://www.tesev.org.tr/dis-politika-programi/Program/6.html.

Akyol, Arzu. 2014. “Türk Dizilerini Dünyada 400 Milyon Kişi İzliyor”. Akşam, June 15. http:// www.aksam.com.tr/pazar/turk-dizilerini-dunyada-400-milyon-kisi-izliyor/haber-315819.

Aljazeera. 2008. "Saudi Scholar Issues TV Death Fatwa”. Aljazeera, September 13. http://www. aljazeera.com/news/middleeast/2008/09/2008913181844832341.html.

Aljazeera. 2014. “Türk Dizilerinin Rekoru”. Aljazeera, February 21. http://www.aljazeera.com. tr/al-jazeera-ozel/turk-dizilerinin-rekoru.

Almutawa, Shatha. 2014. "Magnificent century:Historical Turkish Soap Opera finds a Global Audience". AHA Today:A Blogofthe American HistoricalAssociation, July29. http://blog.historians. org/2014/07/magnificent-century-historical-turkish-soap-opera-finds-global-audience/.

Altamimi, Jumana. 2012. "Challange of the Turkish Soap Operas.” Gulf News, April 1. http://gulfnews.com/business/sectors/features/challenge-of-the-turkish-soap-operas-1.1002249.

Altayl, Fatih. 2013. “Türk Dizileri Niye Başarılı?” Habertürk, August 18. http://www.haberturk. com/yazarlar/fatih-altayli/869872-turk-dizileri-niye-basarili.

Anatolia News Agency. 2013. “Turkish Sopa Operas Take Bulgaria by Storm”. Hürriyet Daily News, June 13. http://www.hurriyet.com.tr/english/domestic/11855675_p.asp.

Athens Owl. 2014. "How Turkish Soap Operas have affected Greece and the Arab World". Athens Owl Blog, October 18. https://aristotelion.wordpress.com/2014/10/18/how-turkish-soapoperas-have-affected-greece-the-arab-world/.

Ball1, Faruk, et al. 2013. "Impacts of Exported Turkish Soap Operas and Visa-Free Entry on Inbound Tourism in Turkey". Elsevier Science 37: 180-192.

Bilbassy-Charters, Nadia. 2010. "Leave it to Turkish soap to conquer hearts and minds". Foreign Policy Group: The Middle East Channel, April 15. http://foreignpolicy.com/2010/04/15/ leave-it-to-turkish-soap-operas-to-conquer-hearts-and-minds/.

Buccianti, Alexandra. 2010. "Dubbed Turkish Soap Operas Conquering the Arab World: Social liberation or cultural alienation". Arab Media and Society 10. http://www.arabmediasociety. com/?article $=735$.

Chesterman, Andrew. 2007. "Bridge Concepts in Translation Sociology". In Constructing a Sociology of Translation, ed. by Michaela Wolf and Alexandra Fukari, 171-186. Amsterdam: John Benjamins. doi:10.1075/btl.74.12che

Çevik, Senem. 2014. "Turkish Soap Opera Diplomacy: A Western Project by a Muslim Source”. Exchange Journal of Public Diplomacy 5: 77-102.

De Marco, Marcella. 2012. Audiovisual Translation through a Gender Lens. Amsterdam: Rodopi.

Diaz Cintas, Jorge. 2009. New Trends in Audiovisual Translation. Bristol: Mutlilingual Matters. doi: $10.1057 / 9780230234581$

Díaz Cintas, Jorge. 2012. "Clearing the smoke to see the screen: Ideological manipulation in audiovisual translation". Meta. 57 (2): 279-293. doi:10.7202/1013945ar

Dick, Jennifer K. and Stephanie Schwerter (eds.). 2012. Transmissability and Cultural Transfer: Dimensions of Translation in the Humanities. Stuttgart: İbidem-Verlag. 
Ekopolitika. 2015. “Türk Dizileri Arap Ülkelerinde Boşanma Furyası Başlattı”. Avrupalı Türklerin Platformu Ekopolitika, June 21. http://www.ekopolitika.de/page.php?id=171.

Erdbrink, Thomas. 2013. "Starring in Drama in Iran: TV Itself". The New York Times, Middle East Tehran Journal, January 14. http://www.nytimes.com/2013/01/15/world/middleeast/ soap-operas-disappearance-adds-to-tv-drama-in-iran.html.

Feral, Anne-Lise. 2011. "Gender in audiovisual translation: Naturalizing feminine voices in the French Sex and the City”. European Journal of Women's Studies 18 (4): 391-407. doi:10.1177/1350506811415199

Flynn, Rachel. 2014. "Language, culture and censorship: A Glimpse into the World of Audiovisual Translation”. Rachel Flynn Blog Discussions in Translation Studies. April 14. https:// racheljeanflynn.wordpress.com/2014/04/14/language-culture-and-censorship-a-glimpseinto-the-world-of-audiovisual-translation/.

Gamal, Muhammed Y. 2014. "Audiovisual translation in the Arab World: Mapping the Field". Arab Media and Society 19. http://www.arabmediasociety.com/?article=851.

Gambier, Yves. 2003. "Introduction: Screen translation perception and reception". The Translator 9 (2): 171-189. doi:10.1080/13556509.2003.10799152

Gambier, Yves. 2006. "Multimodality and Audiovisual Translation”. In Proceedings of the Marie Curie Euroconferences MuTra: Audiovisual Translation Scenarios, 1-8. Copenhagen, May $1-5$.

Gök, Seda. 2015. “Türk Dizileri Dünya Liderliğine Oynuyor”. Seda Gök’ün Haber Sitesi, March 15. http://www.sedagok.com/?p=293.

Gubash, Charlene. 2008. "Soap Opera Upends Traditional Arab Gender Roles". NBC News, July 31. http://worldblog.nbcnews.com/_news/2008/07/31/4376465-soap-opera-upendstraditional-arab-gender-roles.

Günerhan, Ayla. 2014. “Ojala! Şehrazat Mutlu Olur”. Hürriyet Kelebek, September 22. http:// www.hurriyet.com.tr/kelebek/hayat/27196471.asp.

Haberport. 2015. "Dünya Hangi Türk Dizilerini Beğeniyor”. Haberport, April 2. http://www. haberport.com/medya/dunya-hangi-turk-dizilerini-begeniyor-h874.html.

Haber Türk. 2011. "Adını Rekor Koyduk”. Haber Türk, December 10. http://www.haberturk. com/medya/haber/695896-adini-rekor-koyduk-galeri.

Hamzic, Amina, Maja Nedelkovska, Donjeta Demolli, and Nemanja Cabric. 2013. "Turks Bewitch the Balkans With their Addictive Soaps". Balkan Insight. http://www.balkaninsight.com/en/article/turks-bewitch-the-balkans-with-their-addictive-soaps.

Hürriyet. 2012. "Macedonia Bans Turkish Soap Operas". Hürriyet Daily News. November 14. http://www.hurriyetdailynews.com/macedonia-bans-turkish-soap-operas.aspx?pageID= 238\&nid=34636.

Jawad, Adil. 2013. "Some in Pakistan Threatened by Turkish TV Invasion”. Yahoo News, November 26. http://news.yahoo.com/pakistan-threatened-turkish-tv-invasion-070455011.html.

Kaya, Canan. 2014. "Binbir Gece’nin şaşırtan başarısı- Türk dizileri Güney Amerika dizi piyasasında Arjantin ve Brezilya’nın tahtını sarsmaya başladı”. Hürriyet, September 11. http://www.hurriyet.com.tr/kelebek/paparazzi/27179711.asp.

Kimmelman, Micheal. 2010. “Turks put twist in Racy Soaps”. New York Times, June 17. http://www.nytimes.com/2010/06/18/arts/18abroad.html?_r=0.

Khawaja, Hafsa. 2013. "Pakistan hit by fever of Turkey's popular cultural export". Hafsa Khawaja's Blog, March 16. https://hafsakhawaja.wordpress.com/2013/03/16/pakistan-hit-by-fever-ofturkeys-popular-cultural-export/. 
Krajeski, Jenna. 2012. “Turkey: Days of our lives”. Pulitzer Center on Crises Reporting, March 30. http://pulitzercenter.org/reporting/turkey-diyarbakir-kurdish-roles-soap-opera-politicsayrilik-olmasaydi.

Makris, A. 2012. "Bishop Antimos Hits Out at Turkish Soap Operas Fans". Greek Reporter, October 30. http://greece.greekreporter.com/2012/10/30/bishop-anthimos-hits-out-atturkish-soap-fans/.

Matthews, Owen. 2011. “Turkish Soap Operas Are Sweeping the Middle East”. Newsweek, September 5. http://www.newsweek.com/turkish-soap-operas-are-sweeping-middle-east67403.

Mendillioğlu, Ali. 2014. “Türk Dizileri Balkanlar’da Neden Bu Kadar Popüler?” Dipnot, October 6. http://www.dipnot.tv/turk-dizileri-balkanlarda-neden-bu-kadar-populer/78095/.

Moore, Robbie. 2013. "Soap Opera Diplomacy: Turkish TV in Greece". Yale Global Online, quoted from Article by Robbie Moore in The Independent, February 27. http://yaleglobal. yale.edu/content/soap-opera-diplomacy-turkish-tv-greece.

Oltra Ripoll, Maria D. 2005. “The Translation of cultural references in the cinema”. In Less Translated Languages, ed. by Albert Branchadell and Lovell Margaret West, 75-94. Amsterdam: John Benjamins. doi:10.1075/btl.58

Oxford Bussiness Group. 2015. "Soap Power: The Sweeping Success of Turkish television series". Oxford Business Group. http://www.oxfordbusinessgroup.com/overview/soap-powersweeping-success-turkish-television-series.

Özyurt, Olkan. 2014. "Dünyada İzlenen Türk Dizileri Kadınların Hayatına Dokundu”. Sabah, February 2. http://www.sabah.com.tr/pazar/2014/02/02/dunyada-izlenen-turk-dizilerikadinlarin-hayatina-dokundu?paging=3.

Paschalidou, Nina Maria. 2014. "Kısmet: How Soap Operas Changed the World: Filmmakers View". Aljazeera, January 15. http://www.aljazeera.com/programmes/witness/2013/11/ kismet-how-soap-operas-changed-world-20131117152457476872.html.

RFE/RL Uzbek Service. 2015. “Turkish Soap Operas Taken Off Air in Uzbekistan”. Radio Free Europe Rabio Liberty, June 16. http://www.rferl.org/content/turkish_soap_operas_taken_ off_air_in_uzbekistan/24494989.html.

Rohde, David. 2012. “The Islamic World's Culture Wars Played Out on TV Soap Operas”. The Atlantic, March 9. http://www.theatlantic.com/international/archive/2012/03/the-islamicworlds-culture-war-played-out-on-tv-soap-operas/254247/.

Rousselin, Mathieu. 2013. “Turkish Soap Power: International Perspectives and Domestic Paradoxes”. Euxeinos, October. University of St Gallen. http://www.academia.edu/12881322/16_ Euxeinos_10_2013_Turkish_Soap_Power_International_Perspectives_and_Domestic_ Paradoxes.

Salem, Paul. 2011. “Arap Dünyasında Türkiye’nin Imajı”. TESEV Yayınları. http://www.tesev.org. tr/arap-dunyasinda-turkiye-nin-imaji/Icerik/171.html.

Scott, J. 2011. “Audiovisual Translation: Culture Versus Translation”. Trusted Translations Translation Blog, November 17. http://translation-blog.trustedtranslations.com/audiovisualtranslation-cinema-and-culture-2011-11-17.html.

Sinanidis, Mary. 2015. "Daze of our Lives". Odyssey: The World of Greece, January-February. http://www.odyssey.gr/artsLiving/articles 54 daze article.

Superhaber. 2014. “Türk Dizileri Brezilya’da Maçtan Bile Çok İzleniyor1.” Source cited as Aljazeera.com.tr, November 3. http://superhaber.tv/haber/turk-dizileri-brezilyada-millimactan-bile-cok-izleniyor. 
Turkish Review. 2014. “Turkish soap operas, Arab viewers and censorship”. Turkish Review, July 1. http://www.turkishreview.org/reports/turkish-soap-operas-arab-viewers-andcensorship_540937.

Tursunbaeva, Kanykei. 2014. “Central Asia’s Rulers View Turkish Soap Power with Suspicion”. Global Voices, August 7. http://globalvoicesonline.org/2014/08/07/central-asias-rulersview-turkish-soap-power-with-suspicion/.

Vivarelli, Nick. 2013. “Turkish Soaps Slip by Middle East Censors”. Variety, October 9. http:// variety.com/2013/biz/global/turkish-soaps-slip-by-middle-east-censors-1200706654/.

Williams, Nathan. 2013. “The rise of Turkish soap power". BBC News, June 28. http://www.bbc. com/news/magazine-22282563.

Yasser, Nayera. 2015. "Zawya discussses impact of Turkish soap operas on Arab Women". Daily News Egypt, May 20. http://www.dailynewsegypt.com/2015/05/20/zawya-discussesimpact-of-turkish-soap-operas-on-arab-women/.

Yusuf, Huma. 2013. “The Geopolitics of Soap Operas”. The New York Times, January 10. http:// latitude.blogs.nytimes.com/2013/01/10/the-geopolitics-of-soap-operas/?_r=0.

Zalewski, Piotr. 2013. "As Turkey Turns: Turkish soap operas are one of the country's most unexpected cultural exports and a new source of soft power". The Slate, August 16. http://www. slate.com/articles/arts/roads/2013/08/turkish_soap_operas_go_global_turkey_s_homemade_melodramas_are_popular_across.html.

Zaman. 2014. "Binbir Gece'nin Bulgaristan'daki başarısı Türk dizilerini dünyaya taşıdı”. Zaman, August 1. http://zaman.bg/binbir-gecenin-bulgaristandaki-basarisi-turk-dizilerini-dunyaya-tasidi/.

Zayed, Mohamed. 2013. “Turkish Drama in the Arab World: Social Impacts, Religious Reaction and Dramatic Void in the Arab World”. Research Turkey II (7): 35-42. http://researchturkey.org/author/mohamedzayed/.

\section{Résumé}

Les études qui examinent les implications, les réalités et les difficultés de traduire un seul texte et dans une seule combinaison de langues en donnant une vue d'ensemble plus large de ces traductions et en les étudiant à travers l'impact qu'elles produisent dans les pays auxquels elles sont destinées font partie intégrante de la traductologie. L'étude suivante tente de donner matière à réflexion aux traducteurs audiovisuels de séries télévisées. Des séries télévisées turques ont été diffusées dans 90 pays dans le monde, touchant plus de quatre cents millions de téléspectateurs selon des statistiques du secteur datant de 2014. L'objectif de l'étude est de déterminer quel est le genre de séries télévisées traduites favorites des téléspectateurs dans les différentes régions du monde. Et ce, pour expliquer, compte tenu du feed-back des experts, du public et des médias locaux et internationaux, pourquoi elles sont regardées et pour étudier les modes et stratégies de traduction utilisés afin d'assurer le succès commercial des traductions sur les marchés destinataires.

Mots-clés: traduction audiovisuelle, séries télévisées turques, impact d'une traduction, sous-titrage, dubbing, remakes, censure 


\section{About the author}

Assist. Prof. Dr. Sirin Okyayuz is a trainer and researcher at Bilkent University Department of Translation and Interpreting in Ankara, Turkey. Her research fields are literary translation, audiovisual translation, translation of popular culture products and translator training. Her articles spanning subjects such as the translation of teen literature, the translation of children's literature, the contribution of translation to the evolution of new literary genres, retranslations, translation and creativity, AVT, the subtitling and dubbing of musicals, remakes and translation, societal realities effecting the production of remakes, training in the AVT classroom, translation of politics, translation of manga, translation of songs for the creation of a new genre of music, have been published in international peer reviewed journals. She is also the author of a book on AVT in Turkey and has contributed to compilations, detailing current remake practices and the investigation of the power relations behind AVT practices. She has translated bestselling novels in the popular genre, books on politics and philosophy, comics, drama for the Turkish State Theatre, adapted children books and also works as an audiovisual translator. She lives in Ankara with her two sons.

Address: Bilkent Universitesi, İnsani Bilimler ve Edebiyat Fakültesi, Mütercim-Tercümanlık Bölümü, Merkez Kampüs, Bilkent 06800, Ankara, Turkey

E-mail: yener@bilkent.edu.tr 